\title{
The Effectiveness of Oral Test-based Educational Videos in Improving Public Understanding about COVID-19
}

\author{
Anisa Firdausi Rahmanda ${ }^{\mathrm{a}}$, Dinna Yusigania Sunandara ${ }^{\mathrm{a}}$ Rania Dita Kemala Putri ${ }^{\mathrm{a}}$, \\ Maftuchah Rochmanti ${ }^{\mathrm{b} *}$ \\ b*Corresponding Author: maftuchah-r@fk.unair.ac.id \\ ${ }^{a}$ Medical Study Program, Faculty of Medicine, University of Airlangga 60132, Surabaya, Indonesia \\ ${ }^{b}$ Department of Anatomy, Histology, and Pharmacology, Faculty of Medicine, University of Airlangga 60132, Surabaya, Indonesia
}

\begin{abstract}
The Coronavirus Disease (COVID-19) pandemic encourages the importance of online education about health to increase understanding and awareness about COVID-19. The amount of information scattered makes it difficult for people to choose the wrong and correct information. Education based on trusted and easy-to-access sources must be done during a pandemic. This activity is in line with the Sustainable Development Goals (SDGs) to improve the prosperity of the global community, especially in the public health sector. Education was carried out by conducting an oral test on ten samples regarding their opinions and knowledge about COVID-19. The test results were published as part of educational videos uploaded on YouTube and IGTV channels. At the end of the activity, a post-test was conducted on 36 respondents to determine their level of understanding after watching educational video. The evaluation results from the pre-test and posttest that have been carried out have an average increase from $24.29 \%$ to $86.3 \%$, which means there is an increase in understanding health protocols and COVID-19 after watching videos so that educational videos are effectively used as learning media.

Keywords: COVID-19; Education; Educational videos; Youtube; IGTV; Public health
\end{abstract}

\section{Background}

Since March 2020, the World Health Organization has declared COVID-19 a global pandemic. Starting from December 2019 in Wuhan, China, this virus first appeared and spread rapidly to all corners of the world. The SARS-CoV-2 virus, a new strain of the Coronaviridae family, causes COVID-19, . This virus causes symptoms ranging from asymptomatic to acute respiratory distress syndrome to death (Mallah et al., 2021). SARS-CoV-2 can spread by direct contact (droplets and human-to-human transmission) and indirect contact (contaminated objects and airborne transmission). The ease of transmission of this virus contributes to the high number of positive cases (Lotfi, Hamblin, and Rezaei, 2020).

The emergence of new variants of the SARS-CoV-2 virus starting from the Alpha, Beta, Gamma, Delta, and most recently Omicron variants is also one of the causes of the high number of COVID-19 cases. Based on data from the WHO in December 2021, as many as 295 million people have been confirmed positive for COVID-19. The Southeast Asia region ranks third with 45 million cases (WHO, 2021). In Indonesia itself, based on data from the COVID-19 Task Force as of December 2021, the number of cases of COVID-19 has reached a total of 4.2 million cases with 144,000 deaths (Covid-19 Cluster, 2021). This increasing number of cases is not matched by existing health facilities, coupled with the fact that no specific drug can cure this disease, making the COVID-19 pandemic very difficult to eliminate. 
Various efforts have been made to reduce the number of COVID-19 cases. Due to the absence of definitive therapy, prevention is the priority to break the chain of infection transmission. On the world stage, the implementation of a lockdown, an emergency protocol implemented by the authorities to prevent people from leaving certain areas, was first implemented in Wuhan, China, and then followed by many other countries (Kraemer et al., 2020). In Indonesia, the government made a PSBB (Large-Scale Social Restriction) policy as an effort to prevent the spread. The implementation of PSBB is believed to be the most effective way to reduce the rate of transmission of the COVID-19 pandemic. But from research conducted by Herdiana (2020), the implementation of PSBB cannot be carried out properly by the community due to three things, namely the lack of public awareness, the reluctance of the community to comply with the PSBB policy, and the inability of the community to comply with the PSBB policy.

In addition to implementing these regulations, the provision of education to the public is also widely carried out. Education is mainly given regarding the SARS-Cov-2 virus itself and how to prevent it. New habits that must be carried out in a pandemic, such as wearing masks, keeping a distance, and washing hands are very easy to find information. The COVID-19 vaccine has also begun to be distributed in many countries, including Indonesia. Although it does not guarantee $100 \%$ protection, this WHO-approved vaccine can provide a high level of protection against progression to more severe illness and death from disease. However, with so much disinformation, many hoaxes appear, so education must be widely disseminated based on trusted sources. If this disinformation is not handled seriously, it can lead to public distrust of science, resulting in apathy towards COVID-19 which will worsen overall health conditions (Bafadhal and Santoso, 2020).

In line with the sustainable development goals (TPB) or Sustainable Development Goals (SDGs), namely improving the welfare of the global community, especially to support the third goal, namely a healthy and prosperous life (National Development Planning Agency. 2020). Providing education to the public is still needed, especially through social media. Social media is the most widely used place for information about COVID-19 (Juditha, 2020). Various forms of education such as videos, booklets, posters, and articles can be easily accessed.

One of the forms of education is that video has audio and visual elements that can improve the individual's experience in understanding content than can be achieved through reading alone (Rasul, Bukhsh, and Batool, 2011). The use of video also has several advantages, namely being able to explain an event, being able to enrich an explanation by integrating it with other media such as text and images, and being able to repeat certain parts to see the picture more focused (Batubara \& Ariani, 2016). Yudianto's (2017) research states that video media is the most appropriate educational medium in conveying messages and will greatly help to understand.

Based on the above background and the limitations of the method of providing face-to-face education to the public, the use of video as an online education medium is expected to provide effective education. Effective education about health will impact public health behavior (Notoatmodjo, 2012), especially during the critical times of the COVID-19 pandemic, where health protocols must be carried out correctly at all times. Improved public understanding and knowledge of the behavior of preventing the transmission of COVID-19 disease will reduce the number of cases (Law, Leung, and Xu 2020).

\section{Implementation Method}

This study uses a qualitative approach. The data collection technique uses primary pre-test data derived from the results of an oral test through a Zoom meeting and a post-test in the form of a questionnaire using Google Form. The subjects in this study were people with an age range of teenagers (12-25 years) and young adults (26-35 years). The method of data analysis was to compare the results of the average pre-test and posttest scores. Data processing techniques include data collection, analysis, and interpretation of data. As an 
indicator of success, research is said to be effective if there is an increase in the average pre-test and post-test scores. The pre-test was obtained from the results of an oral test through the Zoom application, while the posttest was obtained from the results of filling out questionnaires by people who had watched the video.

Online education begins by conducting an oral test using a Zoom meeting on July 9, 2021, to 10 samples. In qualitative research, samples are not taken by taking into account the number but rather the selection of sources of information that aim to obtain complete and representative data. In this study, samples were taken of adolescents (12-25 years) and young adults (26-35 years) as a representation because in 2020 the most internet users were in the youth group as much as $25 \%$ and young adults as much as $17 \%$ (Association of Internet Service Providers). Indonesia, 2020).

Before carrying out the test, the ten people had agreed to give informed consent that the oral test results would be uploaded on YouTube and IGTV channels. The oral test contains 17 questions about clean and healthy living behavior, health protocols, symptoms of COVID-19, and vaccinations. The oral test results are presented in the form of a video as an illustration of public knowledge about COVID-19 and education is added at the end of the video. On July 16, 2021, the video was uploaded on YouTube and IGTV channels. In the current pandemic era, internet users, especially social media, have increased dramatically compared to previous years. This increase is used to disseminate educational videos on the YouTube and Instagram platforms. YouTube was chosen because based on data from the APJII Internet Survey by the Association of Indonesian Internet Service Providers (2020) in Indonesia, 96\% of respondents watched You Tube channels as a medium to find various content. Instagram was chosen because in 2021 around $80 \%$ of Instagram users have an age range of 13-34 years, according to the specified target audience, namely teenagers and young adults. Both platforms have the advantage of being free and easily accessible to the wider community. The post-test was carried out on July 17, 2021, after it was confirmed that the sample had watched the educational video.

\section{Results and Discussion}

\subsection{Oral Pre-Test via Zoom Meeting}

A pre-Test is done face-to-face via the Zoom application. The researcher asked 17 questions with details of 10 questions regarding the opinion/response of the sample regarding COVID-19 and seven oral test questions related to knowledge of COVID-19 covering the sub-themes of clean and healthy living behavior, health protocols, symptoms of COVID-19, and vaccination. Table 1 shows a list of questions and the results of the tests carried out. Of the ten respondents obtained the correct value with an average of $24.29 \%$. Furthermore, from the oral test results, an educational video was made to describe public opinion and knowledge regarding COVID-19. Before taking the test, the ten people had agreed that the results of their oral test would be uploaded on YouTube and IGTV channels.

Table 1. List of Questions and Respondents' Answer Results

\begin{tabular}{clcc}
\hline $\begin{array}{l}\text { Question } \\
\text { Number }\end{array}$ & \multicolumn{1}{c}{ Question } & Correct answer (\%) & Wrong answer (\%) \\
\hline 1 & Length from 5M & $2(20)$ & $8(80)$ \\
2 & PHBS stands for & $3(30)$ & $7(70)$ \\
3 & PPKM stands for & $3(30)$ & $7(70)$ \\
4 & How is the recommendation to wear a mask now & $4(40)$ & $6(60)$ \\
5 & How to wash hands properly and correctly & $1(10)$ & $9(90)$ \\
6 & What is the correct cough etiquette? & $2(20)$ & $8(80)$ \\
7 & What are the symptoms of COVID-19 & $2(20)$ & $8(80)$ \\
\hline TOTAL & & $\mathbf{1 7 ( 2 4 . 2 9 )}$ & $\mathbf{5 3 7 5 . 7 1 )}$ \\
\hline
\end{tabular}




\subsection{Online Education Through Youtube and IGTV}

The education is presented in the form of a video with a duration of 9 minutes 34 seconds with the title "Jawaban Mereka Ketika Ditanya Tentang Pandemi Covid-19..." uploaded to the YouTube metaco21 and IGTV accounts @metaco.21 simultaneously on July 16, 2021 at 12.00 WIB. YouTube account users can watch the educational video through the metaco21 YouTube account homepage (Picture 1) or Instagram users can watch it via IGTV Instagram @ metaco.21 (Picture 2). The educational video uploaded on YouTube and IGTV channels on July 16, 2021 has been watched 511 times.

Fig. 1. The home page of the metaco21 YouTube account

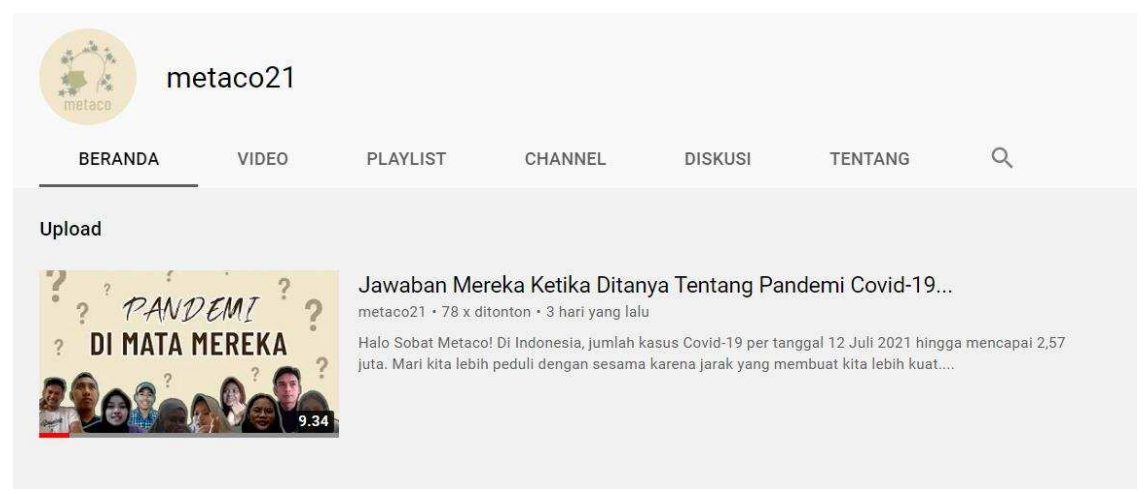

Fig. 2. Display of IGTV Instagram account @ metaco.21

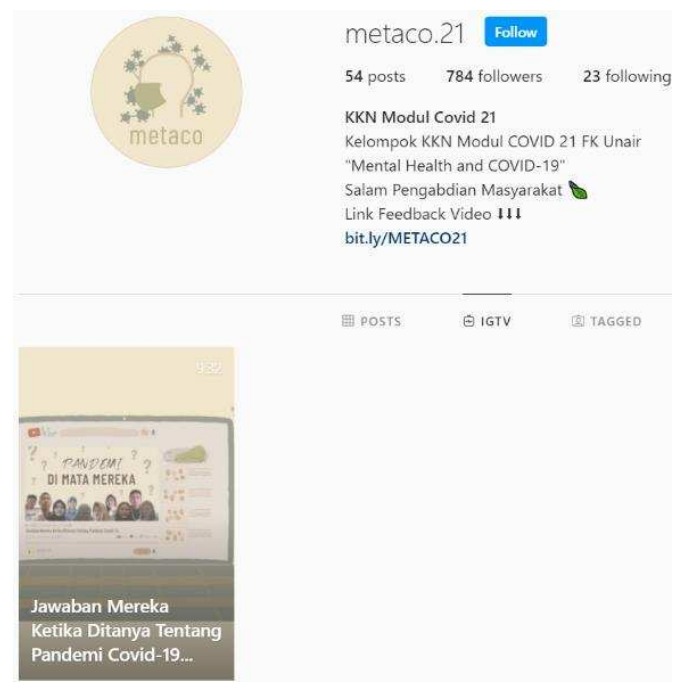

Educational videos consist of various elements such as animation, audio, and text. The educational video content contains the results of an oral test of 10 samples of the community and ends with education about things that the public must know about COVID-19 in general. The educational section at the end of the video is created using animation. Videos that contain animations tend to increase the effectiveness in the learning process because video content looks more fun and easier to understand (Martiya, 2020). 
The educational content provided at the end of the video contains the latest news on COVID-19 cases in Indonesia, recommendations for carrying out clean and healthy living behavior during the pandemic, which includes 5M; a tutorial on how to wash hands properly and correctly; and cough etiquette, how to recognize the symptoms of COVID-19 along with recommendations for checking when experiencing these symptoms, and information related to vaccination.

\subsection{Post-test}

The post-test was conducted on July 17, 2021, with the number of post-test respondents as 36 people. Table 1 shows that most of the respondents belong to the late teens aged 17-25 years (83\%) as many as 30 respondents. Early adolescence is the second-largest category, with five respondents (13.9\%). They are then followed by the category of early adults aged 26-35 years $(2.8 \%)$ with one respondent. Respondents were dominated by women as many as 26 respondents with a percentage of $72.2 \%$ compared to male respondents with as many as ten respondents with $27.8 \%$.

Table 2. Characteristics of Respondents

\begin{tabular}{lcc}
\hline \multicolumn{1}{c}{ Characteristics of Respondents } & $\begin{array}{c}\text { Number of Respondents } \\
(\mathbf{n = 3 6})\end{array}$ & $\begin{array}{c}\text { Percentage } \\
(\boldsymbol{\%})\end{array}$ \\
\hline Age & & \\
$12-16$ (early teens) & 5 & 13.9 \\
13-25 (late teens) & 30 & 83.3 \\
26-35 (early adulthood) & 1 & 2.8 \\
\hline Gender & & \\
Man & 10 & 27.8 \\
Woman & 26 & 72.2 \\
\hline
\end{tabular}

The post-test questions consist of 10 questions (Table 3) regarding COVID-19 and health protocols distributed via Google Form. Based on the distribution of respondents' scores (Figure 3), the post-test scores of respondents are in the range of 40-100. The majority of respondents got a score of 100 (maximum score) with a total of 13 respondents from a total of 36 respondents, and the lowest score was 40 with a total of 1 respondent from 36 respondents. The average respondent who did ten post-test questions got a score of 86.39.

Fig. 3. Distribution of Respondents Value

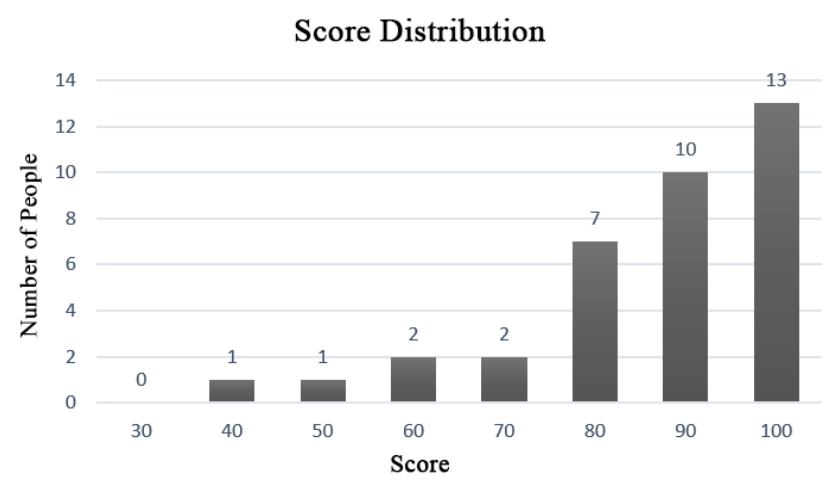


Table 3. Problem Post-test

\begin{tabular}{lcll}
\hline \multicolumn{1}{c}{ Theory } & Number & & \multicolumn{1}{c}{ About } \\
\cline { 1 - 2 } Health Protocol & 1 & Which includes 5M, except \\
$5 \mathrm{M}$ & 2 & PHBS abbreviation \\
PHBS & 3 & PPKM abbreviation \\
PPKM & 4 & What is the recommendation for wearing a mask at this time? \\
Mask recommendation & 5 & How long does it take to wash hands properly \\
Washing hands & 6 & When coughing and sneezing, cover it with both hands \\
Cough etiquette & 7 & Symptoms of COVID-19, except \\
COVID-19 & 8 & People without symptoms recover longer than people with symptoms \\
Symptom & 9 & Getting tested for COVID-19 can reduce the spread of COVID-19 \\
Patient Classification & 10 & Fever is one of the side effects after vaccination \\
Screening & &
\end{tabular}

Based on table 4 and 5, post-test questions with 5M material, COVID-19 screening, and vaccines, the percentage of correct and incorrect answers is $97.2 \%$, and the percentage of wrong answers is $2.8 \%$. For PHBS material, $80.6 \%$ of correct answers and $19.4 \%$ of incorrect answers were given. In material about PPKM, washing hands, coughing, and sneezing etiquette got $83.3 \%$ correct answers and $16.7 \%$ wrong answers. In the material recommended for masks, the percentage of correct answers is $94.4 \%$, and the percentage of incorrect answers is 5.6\%. Then on the COVID-19 symptom material, the percentage of correct answers is $61.1 \%$, and the percentage of wrong answers is $38.9 \%$. Meanwhile, for the classification of COVID-19 patients, $86.1 \%$ of correct answers and $13.9 \%$ of incorrect answers were given.

Table 4. Percentage of Respondents' Answers

\begin{tabular}{|c|c|c|c|c|c|}
\hline Theory & Question Number & Correct answer & $\%$ & Wrong answer & $\%$ \\
\hline \multicolumn{6}{|l|}{ Health Protocol } \\
\hline $5 \mathrm{M}$ & 1 & 35 & 97.2 & 1 & 2.8 \\
\hline PHBS & 2 & 29 & 80.6 & 7 & 19.4 \\
\hline PPKM & 3 & 30 & 83.3 & 6 & 16.7 \\
\hline Mask recommendation & 4 & 34 & 94.4 & 2 & 5.6 \\
\hline Washing hands & 5 & 30 & 83.3 & 6 & 16.7 \\
\hline Cough etiquette & 6 & 30 & 83.3 & 6 & 16.7 \\
\hline Ave & & & 87 & & 13 \\
\hline
\end{tabular}

Table 5. Percentage of Respondents' Answers

\begin{tabular}{|c|c|c|c|c|c|}
\hline Theory & Question Number & Correct answer & $\%$ & Wrong answer & $\%$ \\
\hline \multicolumn{6}{|l|}{ COVID-19 } \\
\hline Symptom & 7 & 22 & 61.1 & 14 & 38.9 \\
\hline Patient Classification & 8 & 31 & 86.1 & 5 & 13.9 \\
\hline Screening & 9 & 35 & 97.2 & 1 & 2.8 \\
\hline Vaccine & 10 & 35 & 97.2 & 1 & 2.8 \\
\hline \multicolumn{2}{|c|}{ Average } & & 85.4 & & 14.6 \\
\hline
\end{tabular}




\subsection{Data Analysis}

Based on the pre-test and post-test data above, it looks that there was an increase in respondents' understanding between before and after watching educational videos. Compared to the pre-test, the average post-test result increased from $24.29 \%$ to $86.3 \%$, so there is an increase in understanding regarding health protocols and COVID-19 after watching educational videos.

In the post-test answers, it is known that respondents can answer correctly more on health protocol materials with an average percentage of $87 \%$, which shows that respondents already understand health protocols. This is in line with Yanti B et al. (2020) research, which said that the Indonesian people have good knowledge of COVID-19 prevention efforts. Fifty-nine respondents (65\%) have a good attitude regarding COVID-19 prevention. In another study conducted by Sukesih et al. (2020), it was stated that the attitude of health students in preventing COVID-19 in Indonesia was highest in the category of good attitude, and 71 respondents $(78.9 \%)$ had good actions in preventing COVID-19. The same results in research conducted by Utami (2020) stated that the people of DKI Jakarta Province with $70.3 \%$ of respondents, had good knowledge, attitudes, and action skills regarding COVID-19 prevention.

Regarding the COVID-19 material, mainly focusing on the symptoms, many respondents still chose the wrong answer because there were a lot of hoax news and symptom updates that kept growing so that people did not know about it even though it was widely circulated in the media. Information about COVID-19 has spread widely in various mass media. Nevertheless, the information obtained is not necessarily correct. Society becomes challenging to choose and sort out which information they should believe. According to research conducted by Juditha (2020), most people have doubts and are in a position where sometimes they can distinguish between hoaxes. Sometimes they do not know because of the large amount of information that can be obtained in one day, and the public panic about COVID-19, so that various information from reliable sources continues - disseminated in the hope that it can be helpful for preventing or treating.

\section{Conclusions and Suggestions}

From the study results, it can be concluded that oral test-based educational videos are effectively used as learning media. It can be seen from the comparison of pre-test and post-test results. After education, there was an increase in knowledge through videos regarding COVID-19 material and health protocols. The use of oral test-based educational videos can be chosen as an educational medium in many fields, not just public health. It is hoped that this method can reach a broader community to determine the level of further effectiveness for more representative results. The proper use of YouTube and Instagram as media for distributing educational video content is also expected to be increased because they can reach the wider community.

\section{Acknowledgements}

The authors would like to express their gratitude to Yulita Kirana, Navia Irfani Nabila, Echa, Betsi, Mukhlishoh Husna Ulfiah, Shinta Nur Khofifah, Uqi, Rafli, Asyam Hafizh Taqiyuddin Setiawan, Luki Ramdani, Alamulhuda, who have been willing to be sampled in the video and 36 post-test respondents.

\section{References}

Asosiasi Penyelenggara Jasa Internet Indonesia. (2020). Laporan Survei Internet APJII 2019 - 2020 (Q2). Diakses 7 Januari 2022. [online] Available at: 〈https://apjii.or.id/survei2019x> 
Badan Perencanaan Pembangunan Nasional. (2020). Pedoman Teknis Penyusunan Rencana Aksi Tujuan Pembangunan Berkelanjutan (TPB) atau Sustainable Development Goals (SDGS) Edisi II. Jakarta: Kedeputian Bidang Kemaritiman dan Sumber Daya Alam, Kementerian Perencanaan Pembangunan Nasional/Badan Perencanaan Pembangunan Nasional.

Bafadhal, O., \& Santoso, A., (2021). Memetakan Pesan Hoaks Berita Covid-19 di Indonesia Lintas Kategori, Sumber, dan Jenis Disinformasi. Diakses 30 juli 2021. [online] Available at: 〈https://journal.ubm.ac.id/index.php/bricolage/article/view/2148>

Batubara, H., \& Ariani, D. (2016). Pemanfaatan Video sebagai Media Pembelajaran Matematika SD/MI. Muallimuna, 2(1), 47-66.

Herdiana, Dian. (2020). Implementasi Kebijakan Pembatasan Sosial Berskala Besar (PSBB) sebagai Upaya Penanggulangan Corona Virus Disease 2019 (COVID-19). Jurnal Administrasi Publik, [S.1.], v. 2, n. 2. ISSN 2656-4939. Available at: <https://journal.unpas.ac.id/index.php/decision/article/view/2978>

Juditha, C. (2020). Perilaku masyarakat terkait Penyebaran Hoaks Covid-19. Pekommas, 5(2), pp.105-116.

Kraemer, M., Yang, C., Gutierrez, B., Wu, C., Klein, B., Pigott, D., du Plessis, L., Faria, N., Li, R., Hanage, W., Brownstein, J., Layan, M., Vespignani, A., Tian, H., Dye, C., Pybus, O. \& Scarpino, S., (2020). The effect of human mobility and control measures on the COVID-19 epidemic in China. Science, 368(6490), pp.493-497.

Law, S., Leung, A. \& Xu, C., (2020). Severe acute respiratory syndrome (SARS) and coronavirus disease-2019 (COVID-19): From causes to preventions in Hong Kong. International Journal of Infectious Diseases, 94, pp.156-163.

Lotfi, M., Hamblin, M. \& Rezaei, N., (2020). COVID-19: Transmission, prevention, and potential therapeutic opportunities. Clinica Chimica Acta, 508, pp.254-266.

Mallah, S., Ghorab, O., Al-Salmi, S., Abdellatif, O., Tharmaratnam, T., Iskandar, M., Sefen, J., Sidhu, P., Atallah, B., El-Lababidi, R. \& Al-Qahtani, M., (2021). COVID-19: breaking down a global health crisis. Annals of Clinical Microbiology and Antimicrobials, 20(1).

Martiya, H. (2020). Efektivitas Penggunaan Video Animasi dalam Proses Pembelajaran Ilmu Pengetahuan Alam (IPA) Kelas VIII Sekolah Menengah Pertama Negeri 23 Muaro Jambi. Jambi: UIN Sutha Jambi

Notoatmodjo, Soekidjo. (2012). Metodologi Penelitian Kesehatan. Jakarta: Rineka Cipta

Rasul, S., Bukhsh, Q. \& Batool, S., (2011). A study to analyze the effectiveness of audio visual aids in teaching learning process at university level. Procedia - Social and Behavioral Sciences, 28, pp.78-81.

Rukajat, A. (2018). Pendekatan Penelitian Kualitatif (Qualitative Research Approach). Deepublish.

Satuan Penanganan COVID-19. (2021). Data Covid-19 Negara Republik Indonesia. Available at: 〈covid19.go.id>

Sukesih, S., Usman, U., Budi, S. \& Sari, D., (2021). Pengetahuan dan Sikap Mahasiswa Kesehatan tentang Pencegahan Covid-19 di Indonesia. Available at: 〈http://dx.doi.org/10.26751/jikk.v11i2.835>

Tarchi, C., Zaccoletti, S. \& Mason, L., (2021). Learning from text, video, or subtitles: A comparative analysis. Computers \& Education, 160, p.104034.

Utami, R., Mose, R. \& Martini, M., (2020). Pengetahuan, Sikap dan Keterampilan Masyarakat dalam Pencegahan COVID-19 di DKI Jakarta. Jurnal Kesehatan Holistic, 4(2), pp.68-77.

World Health Organization. (2020). Archived: WHO Timeline - COVID-19. Available at: <https://www.who.int/news/item/27-04-2020who-timeline---covid-19>

World Health Organization. (2021). WHO Coronavirus (COVID-19) Dashboard. Available at: 〈https://covid19.who.int/>

Yanti, B., Wahyudi, E., Wahiduddin, W., Novika, R. G. H., Arina, Y. M. D., Martani, N. S., \& Nawan, N. (2020). Community Knowledge, Attitudes, and Behaviour Towards Social Distancing Policy as Prevention Transmission of Covid-19 in Indonesia. Jurnal Administrasi Kesehatan Indonesia, 8(2), 4-14.

Yudianto, Arif. (2017). Penerapan Video sebagai Media Pembelajaran. Sukabumi: Seminar Nasional Pendidikan 